\title{
SS-039 ワーキングメモリと実行系機能の可塑性
}

展示棟 /会議室 2

\author{
企画代表者, 話題提供者, 司会者: 坪見 博之 (富山大学) \\ 企画者, 司会者: 艼阪 直行 (京都大学) \\ 話題提供者:森口 佑介 (京都大学) \\ 話題提供者: 苧阪満里子 (情報通信研究機構 / CiNet) \\ 指定討論者: 齊藤 智 (京都大学)
}

ワーキングメモリと実行系機能は, 幅広い高次認知を支える役割を担うことから, 認知心理学的, 脳 科学的なメカニズムが精力的に調べられてきた。メカニズムが明らかになるにつれ，これらがどのよう に発達・遺伝するのか, また, 子どもや成人にワーキングメモリや実行系機能をトレーニングする効果 があるのか, さらには, トレーニングによって日常生活のクオリテイを上げることは可能であるかを検 討する研究が増えてきた。しかし, 単純にワーキングメモリの容量を増やす, 実行系機能を向上させる という試みには限界があることも明らかになりつつある。本シンポジウムでは, このような可塑性と限 界をめぐる研究動向について, 発達と遺伝的視点 (森口), 成人の認知トレーニングからの視点 (坪見), 認知脳科学的視点 (苧阪) から紹介し, この分野の今後のさらなる研究方向についてディスカッション する場としたい。

\section{第2 日 9 月26日(水) $13: 10 \sim 15: 10$}

会議棟 $/$ 白橿 2

\section{SS-040 過程存在論に立った知覚研究の可能性とその意義に関する再検討}

\author{
企画代表者, 話題提供者 : 境敦史 (明星大学) \\ 話題提供者, 司会者: 小松 英海 (慶應義塾大学) \\ 指定討論者: 河野 哲也 (立教大学)
}

研究が認識活動である限り, 研究成果を根拠とした理論は, 必然的になんらかの存在論を前提とする。 例えば, 要素/構成主義心理学では, 要素的感覚こそが存在すると見なされ, 知覚はそれらから構成さ れると考えられた。ゲシュタルト心理学においては, 姿（意味）を持った知覚こそが存在すると見なさ れ, 感覚はその分析から生じる概念である。哲学的な文脈から言えば, 前者は「実体存在論」に, 後者 は「過程存在論」に立っている。さらに, 理論が存在論を前提としている限り, その理論に立つ研究は, その存在論を前提とした方法論を採用することになる。例えば, 実体存在論に立って要素的感覚を存在 者と見なした要素/構成主義心理学では, 存在する要素的感覚を抽出するために分析的内観を採用した。 本シンポジウムの目的は, 過程存在論に立った知覚研究の実例とその成果や意義について多視点的に再 検討し，過程存在論の新たな可能性を模索することである。 